\title{
Vardiyalı Çalışan İş̧ilerde Beslenme Durumu, Uyku Kalitesi ve Metabolik Sendrom Arasındaki İlişki
}

\author{
The Association Between Nutritional Status, Sleep Quality and Metabolic Syndrome among Shift \\ Workers
}

\author{
Gökçe Çakmak ${ }^{1}$ Mevlüde Kızıl²
}

Geliş tarihi/Received: 31.10.2018 • Kabul tarihi/Accepted: 30.11.2018

\section{ÖZET}

Amaç: Vardiyalı çalışmanın sirkadiyen ritimde bozulma, yaşam şekli değişikliği, iş gerginliği ve stres gibi birçok etmenle ilişkili olduğu ve bu durumun sağlık sorunlarını da beraberinde getirdiği düşünülmektedir. Bu çalışmada, vardiyalı çalışmanın beslenme durumu, uyku kalitesi, fiziksel aktivite ve metabolik sendrom (MetS) bileşenleri üzerine etkisinin incelenmesi amaçlanmaktadır.

Bireyler ve Yöntem: Bu çalışma İstanbul'da özel bir güvenlik firmasında vardiyalı çalışan 19-55 yaşları arasında 70 gönüllü birey (16 kadın, 54 erkek) ve 70 normal gün saati çalışan (kontrol) birey (16 kadın, 54 erkek) üzerinde yapılmıştır. Bireylerin demografik özellikleri, fiziksel aktivite kaydı, uyku kalitesi ve üç günlük besin tüketim kayıtları yüz yüze görüşme yöntemiyle soru formu kullanılarak toplanmıştır. Fiziksel aktivite düzeyi IPAQ (International Physical Activity Questionnaire) kısa form kullanılarak, uyku kalitesi Pittsburgh Uyku Kalite İndeksi (PUKİ) kullanılarak değerlendirilmiştir. Ayrıca, bireylerin biyokimyasal bulguları (açlık kan glukozu, HDL-kolesterol, trigliserit düzeyleri) analiz edilmiş, antropometrik ölçümleri (vücut ağırlığı, boy uzunluğu, bel çevresi ve kalça çevresi) ve kan basıncı bulguları alınmıştır.

Bulgular: Bireylerin uyku kaliteleri incelendiğinde vardiyalı çalışan grubun \%58.6’sı kötü uyku kalitesine sahipken kontrol grubunun sadece \%17.1'inin kötü uyku kalitesine sahip olduğu görülmüştür. Vardiyalı çalışan kadınların \%68.8'i hafif şişman veya obez iken, kontrol grubundaki kadınların \%18.8'i hafif şişmandır. Vardiyalı çalışan erkeklerin \%85.2'sinin ise hafif şişman veya obez olduğu saptanmıştır. Uluslararası Diyabet Federasyonu (IDF) 2005’te metabolik sendrom tanı kriterleri tek tek değerlendirildiğinde bel çevresi bileşeni ve MetS görülme oranı açısından gruplar arasında anlamlı fark olduğu görülmüştür $(\mathrm{p}<0.001)$. Bireylerin, enerji ve besin ögesi alımlarına bakıldığında hem kadın hem de erkek vardiyalı çalışanların daha yüksek enerji ve karbonhidrat alımları olduğu görülmektedir $(\mathrm{p}<0.05)$.

Sonuç: Bu çalışma, vardiyalı çalışmanın bireylerin uyku kalitelerini düşüren, obezite ve metabolik sendrom riskini arttıran bir durum olduğunu göstermektedir.

Anahtar kelimeler: Vardiyalı çalışma, obezite, metabolik sendrom, uyku kalitesi, beslenme durumu

\section{ABSTRACT}

Aim: Shift work has been associated with disturbed circadian rhythm, lifestyle change, work related strain and stress, may cause health problems. The aim of this study is to investigate the effect of shift work on nutritional status, sleep quality,

1. Krrklareli Üniversitesi, Sağllk Yüksek Okulu, Beslenme ve Diyetetik Bölümü, Krrklareli, Türkiye • ๑ https://orcid.org/0000-0003-1049-6428
2. İletişim/Correspondence: Hacettepe Üniversitesi, Sağllk Bilimleri Fakültesi, Beslenme ve Diyetetik Bölümü, Ankara, Türkiye

E-posta: mkizil@hacettepe.edu.tr • ๑ https://orcid.org/0000-0003-1380-3243 
physical activity and metabolic syndrome (MetS) components.

Subjects and Methods: This study included 70 volunteer subjects (16 females, 54 males) aged between 19-55 years, working in a private security firm in Istanbul, and 70 normal day-time (control) individuals with same age group(16 women, 54 male). Demographic characteristics, physical activity record, sleep quality and three-day food consumption records were collected by using face-to-face interview method. Sleep quality was assessed using the Pittsburgh Sleep Quality Index (PSQI), using the IPAQ (International Physical Activity Questionnaire) short form of physical activity level was assessed. Biochemical parameters (fasting blood glucose, HDL-cholesterol, Triglyceride levels) were analyzed and anthropometric measurements (body weight, height, waist circumference and hip circumference) and blood pressure measurements were obtained.

Results: When the sleep quality of subjects was examined, $58.6 \%$ of the shift workers had a poor sleep quality and only $17.1 \%$ of the control group had a poor sleep quality. While $68.8 \%$ of women working with shifts were overweight or obese, $18.8 \%$ of women in the control group were overweight. Overall $85.2 \%$ of the men working with shifts were found to be overweight or obese. When the diagnostic criteria of IDF-2005 (International Diabetes Federation) metabolic syndrome were examined one by one, it was seen that there was a significant difference between the groups in terms of waist circumference and rate of metabolic syndrome $(\mathrm{p}<0.001)$. When investigated energy and nutrient intake of subjects, it was seen that both female and male shift workers have higher energy and carbohydrate intake $(\mathrm{p}<0.05)$.

Conclusion: This study shows that shift work is a condition that decreases sleep quality of individuals and increases the risk of obesity and metabolic syndrome.

Keywords: Shift work, obesity, metabolic syndrome, sleep quality, nutritional status

\section{GíRiş}

Çalışmanın veya hizmetin sürekli olduğu durumlarda işin sürekliliğini sağlamak gereklidir ve bunu gerçekleştirebilmek adına, çalışanlar günün değişik vakitlerinde çalışmak durumundadırlar (1). Vardiyalı çalışma sistemi dünyada yaygın olarak uygulanmaktadır ve günümüzdeki sanayi toplumlarında, vardiyalı çalışanların sayısı giderek artmaktadır. Gelişmiş ülkelerin çoğunluğunda çalışanların yaklaşık beşte birinin (\%20) değişik vardiyalar halinde çalıştığı, sürekli olarak gece vardiyasında çalışanların ise \%5-10'luk bir dilimi oluşturduğu bildirilmiştir (2,3). Bazı sektörlerde vardiyalı çalışma oranının \%70’lere ve gece vardiyası oranının ise \%20'lere ulaştığı rapor edilmiştir $(1,4,5)$. Türkiye 2003 yllı verilerine göre çalışan nüfusun \%8'inin yani 1 milyon 691 bin 760 kişinin vardiyalı olarak çalıştığı rapor edilmiştir $(6,7)$.

Vardiyalı çalışmayla ilişkili olarak ortaya çıkan sirkadiyen ritimde bozulma, yaşam şekli değişikliği, iş gerginliği ve stres etmeni sonucu birçok sağlık sorunu ortaya çıkmaktadır (8). Bu sağlık sorunları arasında obezite, kanser, kardiyovasküler hastalık
(KVH), metabolik sendrom (MetS) ve diabetes mellitus (DM) gibi kronik hastalıklar yer almaktadır. Fiziksel ve ruhsal olarak yaşanan bu bozuklukların temelinde vardiya sisteminin yarattığı uyku düzenini bozukluğunun olduğu düşünülmektedir (9,10-12).

Biyolojik saat vücut sıcaklığı, kalp atışı, kan basıncı, besin tüketimi ve elektrolit düzeyleri ile dolaşım gibi vücut işlevlerini normal bir şekilde sürdürmeyi sağlayan bir sistemdir ve kaliteli uyku sirasında vücut immünolojik, kardiyak ve metabolik sistemi destekleyen büyüme hormonlarını salgılamaktadır (13). Düzensiz uyku durumunun vardiyalı çalışanların 3/4’ünde görülen bir sağlık sorunu olduğu bildirilmiştir (1). Birçok çalışma vardiyalı çalışmanın stresi arttırdığı, uyku kalitesini düşürdüğü ve uyku bozuklukları sonucu sağlığın bozulmasına neden olduğunu belirtmektedir (14-16). Çeşitli çalışmalarda da, vardiyalı çalışma ile MetS arasında bir ilişki olduğu gösterilmiştir $(16,17)$. Vardiyalı çalışanlar arasındaki beslenme alışkanlığı değişikliği, azalmış fiziksel aktivite, uyku bozukluğu ve bozulmuş metabolik etki gibi çeşitli mekanizmalar MetS gelişimine katkıda 
bulunmaktadır $(9,11)$. MetS tanı kriterleri ayrı ayrı ve bütün olarak incelendiğinde vardiyalı çalışma ile birlikte görülme oranlarının yüksek olduğu vurgulanmaktadır (8-12). Bu durumun sirkadiyen ritmin vardiyalı çalışmadan etkilenip bozulmasıyla ilişkilendirildiği görülmektedir. $\mathrm{Bu}$ çalışmada vardiyalı çalışmanın beslenme durumu, uyku kalitesi, fiziksel aktivite ve MetS bileşenleri üzerine etkisinin incelenmesi amaçlanmaktadır.

\section{BİREYLER VE YÖNTEM}

\section{Katılımcilar}

$\mathrm{Bu}$ araştırma Haziran ve Temmuz 2016 tarihleri arasında, İstanbul ilinde yaşayan yaş aralığı 19-55 yıl olan, hekim tarafından tanısı konulmuş kronik bir hastalığı olmayan (kalp damar hastalığı, diyabet, hipotroidi vb.), en az 6 ay en fazla 5 yıl süreyle aynı iş yerinde çalışan bireyler üzerinde yürütülmüştür. Çalışmaya katılan bireyler vardiyalı çalışanlar ve gün saati çalışanlar (kontrol grubu) olarak iki gruba ayrılmış, her iki grupta da yaşları 19-55 arasında değişen 70 kişi (16 kadın, 54 erkek) olmak üzere toplam 140 birey araştırma kapsamına alınmıştır.

Bahçeşehir Üniversitesi'nde çalışan güvenlik görevlileri gün saati yönünde ilerleyen dönüşümlü vardiya sistemiyle çalışmaktadır. Vardiyaları üçlü vardiya şeklindedir ve saat aralıkları i) 06.0015.00 , ii) $14.30-23.30$, iii) 23.00-06.30 şeklindedir. $\mathrm{Bu}$ bireylerin vardiyaları iki ayda bir kez değişmektedir. İki aylık çalışma sonunda sabah vardiyasındaki bireyler öğle, öğle vardiyasındaki bireyler gece ve gece vardiyasındaki bireyler sabah vardiyalarma geçmektedir. Çalışmaya 14.30-23.30 vardiyasında çalışan bireyler dahil edilmiştir. Gün saati içinde çalışan bireyler Bahçeşehir Üniversitesi'nde çalışan (idari personel) ve vardiya grubu ile aynı yaş ve cinsiyette olup çalışmaya katılmayı kabul edenlerden oluşmakta ve bu bireyler 9:00-17:30 saatleri arasında çalışmaktadır. Bu çalışma protokolü, Hacettepe Üniversitesi Etik Kurulu tarafindan incelenmiş ve 16969557-525 sayll kararla 24/05/2016 tarihinde onaylanmıştır.

\section{Araştırmanın Genel Planı ve Verilerin Toplanması}

Araştırmaya katılan bireylere ilişkin genel bilgiler (yaş, eğitim, sağlık durumları vb.), beslenme alışkanlıkları, Uluslararası Fiziksel Aktivite Anketi (IPAQ) - kısa form ölçeği, Pitsburgh Uyku Kalite İndeksi (PUKI) (18) ve bir günü hafta sonuna gelecek şekilde birbirini izleyen üç gün (iki gün vardiyalı çalışma günü) boyunca besin tüketim kayıtlarını içeren anket yüz yüze görüşme yöntemi kullanılarak uygulanmıştır. Besin tüketim kayıtları, Beslenme Bilgi Sistemi (BeBis) Programı kullanılarak hesaplanmıştır (19).

Uluslararası Fiziksel Aktivite Anketi (IPAQ)-Kısa formunda toplam skorunun hesaplanması yürüme, orta şiddetli aktivite ve şiddetli aktivitenin süre (dakikalar) ve sıklık (günler) toplamını içermektedir. Bu hesaplamalardan, metabolik eşdeğer (MET)-dakika olarak bir skor elde edilmektedir. Hesaplamalar sonunda sonuçlar sinıflandırılmaktadır $(20,21)$.

Bireylerin antropometrik ölçümleri olarak vücut ağırlığı (kg), boy uzunluğu (cm), bel ve kalça çevresi ölçümleri (cm) gerekli koşullar sağlanarak yöntemine uygun şekilde alınmış $(22,23)$ ve bu ölçümlere göre beden kütle indeksi (BKI) ve bel/kalça oranları hesaplanmıştır.

Ayrıca, bireylerin kan basıncı ölçümleri alınmış ve bazı biyokimyasal bulguları (açlık kan glukozu, HDLkolesterol, trigliserit düzeyleri) özel bir laboratuvar tarafından analiz edilmiştir. Bu çalışmada metabolik sendrom tanı kriteri olarak Uluslararası Diyabet Federasyonunun (IDF)'ın tanı kriterleri kullanılmıştır (24). Tablo 1'de Uluslararası Diyabet Federasyonu (IDF) Metabolik Sendrom Tanı Kriterleri verilmiştir.

\section{Verilerin İstatistiksel Değerlendirmesi}

Tüm veriler SPSS 22.0 istatistik paket programı kullanılarak analiz edilmiştir. Kesikli verilerin basit ve çapraz dağılımları, sayı (n) ve yüzde (\%) tabloları olarak verilmiştir ve ki-kare $\left(\chi^{2}\right)$ testi ve gözelerde frekans sayısının 5’ten küçük olduğu durumlarda Fisher-exact testi uygulanmıştır. Normal dağllan verilerde iki grubun ortalamalarını karşılaştırmak için t-test, normal dağılmayan verilerde ise iki grubun 
ortancalarını karşılaştırmak için Mann Whitney U testi kullanılmıştır. Tüm analizlerde, $\mathrm{p}<0.05$ olması istatistiksel olarak anlamlı farklılık olarak kabul edilmiştir.

Tablo 1. Uluslararası Diyabet Federasyonu (IDF) metabolik sendrom tanı kriterleri

IDF’in tanımına göre metabolik sendrom tanımlaması için aşağıdaki durumların gözlenmesi gerekmektedir:

Abdominal obezite (Avrupalı erkeklerde $\geq 94 \mathrm{~cm}$, kadınlarda $\geq 80 \mathrm{~cm}$ )

Buna ek olarak aşağıdaki dört durumdan en az ikisinin olması:

Yüksek trigliserit değerleri $\geq 150 \mathrm{mg} / \mathrm{dL}(1.7 \mathrm{mmol} / \mathrm{dL})$ veya bu lipit bozukluğu nedeniyle tedavi alıyor olmak

Düşük HDL kolesterol $\quad<40 \mathrm{mg} / \mathrm{dL}(1.03 \mathrm{mmol} / \mathrm{dL})$ - erkekler

$<50 \mathrm{mg} / \mathrm{dL}$ (1.29 mmol/dL) - kadınlar veya bu lipit bozukluğu nedeniyle tedavi alıyor olmak

Yüksek kan basıncı Sistolik kan basıncı $\geq 130$ veya diasitolik kan basıncı $\geq 85 \mathrm{mmHg}$ veya daha önce hipertansiyon tanısı almış olmak

Açlık kan glukozunun $\geq 100 \mathrm{mg} / \mathrm{dL}$ (5.6 mmol/dL) veya daha önce Tip 2 diyabet tanısı almış

Yüksek açlık kan glukozu olmak

Eğer açlık kan glukozu $100 \mathrm{mg} / \mathrm{dL}$ ’nin (5.6 mmol/dL) üzerindeyse oral glukoz tolerans testi (OGTT) önerilmelidir. Ancak bu test metabolik sendrom tanısı için gerekli değildir.

\section{BULGULAR}

Çalışmaya katılan bireylerin çalışma şekillerine göre demografik özellikleri, uyku kaliteleri ve fiziksel aktivite düzeyleri Tablo 2'de verilmiştir. Gruplar arasında yaş, cinsiyet, eğitim durumu, hastalık durumu, ilaç kullanımı ve fiziksel aktivite düzeyleri bakımından istatistiksel olarak anlamlı bir farklılık bulunmamaktadır. Ancak, bireylerin uyku kaliteleri incelendiğinde vardiyalı grubun \%58.6’sı kötü uyku kalitesine sahipken, kontrol grubunun sadece \%17.1'inin kötü uyku kalitesine sahip olduğu görülmüştür ( $\mathrm{p}=0.0001)$.

Çalışmaya katılan bireylerin çalışma şekline göre BKİ sınıflaması ve bel-kalça oranı Tablo 3’te verilmiştir. Vardiyalı çalışan bireylerde obezite görülme oranının normal gün saati çalışan bireylere kıyasla daha yüksek olduğu görülmüştür ( $p<0.05)$. Vardiyalı çalışan kadınların \%31.2'si, vardiyalı çalışan erkeklerin ise \%29.6'sı obezdir.

Kadın katılımcıların BKİ’eri incelendiğinde vardiyalı çalışan kadınların \%31.2'si normal, \%37.6'sı hafif şişman, \% 31.2'si obez, kontrol grubundaki kadınların \%18.8'i zaylf, \%62.4'ü normal ve \%18.8'i hafif şişmandır ( $\mathrm{p}<0.05)$. Erkek katılımcılarda ise vardiyalı çalışanların \%14.8’i normal, \%55.6’sı hafif şişman, \%29.6'sı obez, kontrol grubundakilerin \%77.7'si normal, \%16.7'si hafif şişman ve \%5.6'sı obezdir $(p<0.01)$. Her iki grubun da cinsiyete göre BKİleri arasındaki fark istatistiksel olarak önemlidir.

Kadın katılımcıların bel-kalça oranı incelendiğinde vardiyalı çalışan kadınların \%62.5'i, kontrol grubundaki kadınların ise \%43.8'i normalin üzerinde bel-kalça oranına sahiptir ( $p>0.05)$. Erkek katılımcılarda ise vardiyalı çalışanların \%55.6'sı, kontrol grubundakilerin ise \%13.0'ü normalin üzerinde bel-kalça oranına sahiptir $(p<0.01)$. Kadın katılımcıların çalışma şekillerine göre bel-kalça oranları arasında anlamlı fark bulunmazken, erkek katılımcıların cinsiyete göre bel-kalça oranları arasındaki fark istatistiksel olarak önemlidir.

Çalışmaya katılan bireylerin MetS bileşenlerine göre dağılımları Tablo 4'te verilmiştir. Bireylerin çalışma şekline göre bel çevresi dağılımları arasında istatistiksel olarak anlamlı fark saptanmış $(\mathrm{p}<0.001)$ ve bel çevresinin erkeklerde $\geq 94 \mathrm{~cm}$ ve kadınlarda $\geq 80 \mathrm{~cm}$ üzerinde olma durumu vardiyalı çalışanlarda \%68.6 iken, gün saati çalışanlarda \%22.9 olarak bulunmuştur. 
Tablo 2. Çalışmaya katılan bireylerin genel özellikleri

\begin{tabular}{|c|c|c|c|c|c|c|c|c|}
\hline \multirow{2}{*}{\multicolumn{2}{|c|}{ Özellikler }} & \multicolumn{2}{|c|}{ Vardiyalı grup } & \multicolumn{2}{|c|}{ Kontrol grubu } & \multicolumn{2}{|c|}{ Toplam } & \multirow{2}{*}{$\mathbf{P}^{\S}$} \\
\hline & & $\mathbf{n}$ & $\%$ & $\mathbf{n}$ & $\%$ & $\mathbf{n}$ & $\%$ & \\
\hline \multirow{5}{*}{ Yaş (yıl) } & $19-24$ & 5 & 7.1 & 5 & 7.1 & 10 & 7.1 & \multirow{5}{*}{$>0.05$} \\
\hline & $25-34$ & 45 & 64.3 & 45 & 64.3 & 90 & 64.3 & \\
\hline & $35-44$ & 17 & 24.3 & 17 & 24.3 & 34 & 24.3 & \\
\hline & $45-54$ & 3 & 4.3 & 3 & 4.3 & 6 & 4.3 & \\
\hline & Toplam & \multicolumn{2}{|c|}{$32.33 \pm 5.84$} & \multicolumn{2}{|c|}{$32.59 \pm 6.00$} & & & \\
\hline \multirow{2}{*}{ Cinsiyet } & Kadın & 16 & 22.9 & 16 & 22.9 & 32 & 22.9 & \multirow{2}{*}{$>0.05$} \\
\hline & Erkek & 54 & 77.1 & 54 & 77.1 & 108 & 77.1 & \\
\hline \multirow{2}{*}{$\begin{array}{l}\text { Medeni } \\
\text { durum }\end{array}$} & Evli & 34 & 48.6 & 39 & 55.7 & 73 & 52.1 & \multirow{2}{*}{$>0.05$} \\
\hline & Bekar & 36 & 51.4 & 31 & 44.3 & 67 & 47.9 & \\
\hline \multirow{6}{*}{$\begin{array}{l}\text { Eğitim } \\
\text { durumu }\end{array}$} & Okur-yazar & - & - & 1 & 1.4 & 1 & 0.7 & \multirow{6}{*}{$>0.05$} \\
\hline & İlkokul & - & - & 4 & 5.7 & 4 & 2.9 & \\
\hline & Ortaokul & 22 & 31.4 & 12 & 17.1 & 34 & 24.3 & \\
\hline & Lise & 33 & 47.2 & 36 & 51.4 & 69 & 49.3 & \\
\hline & Lisans/ön lisans & 14 & 20.0 & 16 & 22.9 & 30 & 21.4 & \\
\hline & Yüksek lisans + & 1 & 1.4 & 1 & 1.4 & 2 & 1.4 & \\
\hline \multirow{2}{*}{$\begin{array}{l}\text { Hastalık } \\
\text { durumu }\end{array}$} & Hayır & 67 & 95.7 & 70 & 100.0 & 137 & 97.9 & \multirow{2}{*}{$>0.05$} \\
\hline & Evet & 3 & 4.3 & - & - & 3 & 2.1 & \\
\hline \multirow{2}{*}{$\begin{array}{l}\text { İlaç } \\
\text { kullanımı }\end{array}$} & Hayır & 68 & 97.1 & 70 & 100.0 & 138 & 98.6 & \multirow{2}{*}{$>0.05$} \\
\hline & Evet & 2 & 2.9 & - & - & 2 & 1.4 & \\
\hline \multirow{2}{*}{ Uyku kalitesi } & İyi & 29 & 41.4 & 58 & 82.9 & 87 & 62.2 & \multirow{2}{*}{0.0001} \\
\hline & Kötü & 41 & 58.6 & 12 & 17.1 & 53 & 37.8 & \\
\hline \multirow{3}{*}{$\begin{array}{l}\text { Fiziksel } \\
\text { aktivite }\end{array}$} & İnaktif (<600 MET-dk/hafta) & 41 & 58.6 & 39 & 55.7 & 80 & 57.1 & \multirow{3}{*}{$>0.05$} \\
\hline & Az aktif (600-3000 MET-dk/hafta) & 28 & 40 & 29 & 41.4 & 57 & 40.7 & \\
\hline & Çok aktif (>3000 MET-dk/hafta) & 1 & 1.4 & 2 & 2.9 & 3 & 2.2 & \\
\hline
\end{tabular}

Veri ortalama standart sapma ve/veya sayı yüzde olarak olarak verilmiştir.

${ }^{\S}$ Ki-kare $\left(\chi^{2}\right)$ testi ve gözelerde frekans sayısının 5’ten küçük olduğu durumlarda Fisher-exact testi uygulanmıştır.

Tablo 3. Çalışmaya katılan bireylerin BKİ ve bel/kalça oranlarına göre değerlendirilmesi

\begin{tabular}{|c|c|c|c|c|c|c|c|c|c|c|c|c|c|c|}
\hline \multirow{3}{*}{ Değişkenler } & \multicolumn{4}{|c|}{ Vardiyalı grup } & \multicolumn{4}{|c|}{ Kontrol grubu } & \multicolumn{4}{|c|}{ Toplam } & \multirow{2}{*}{\multicolumn{2}{|c|}{$\mathbf{P}^{\S}$}} \\
\hline & \multicolumn{2}{|c|}{ Kadın } & \multicolumn{2}{|c|}{ Erkek } & \multicolumn{2}{|c|}{ Kadın } & \multicolumn{2}{|c|}{ Erkek } & \multicolumn{2}{|c|}{ Kadın } & \multicolumn{2}{|c|}{ Erkek } & & \\
\hline & $\mathbf{n}$ & $\%$ & $\mathbf{n}$ & $\%$ & $\mathbf{n}$ & $\%$ & $\mathbf{n}$ & $\%$ & $\mathrm{n}$ & $\%$ & $\mathbf{n}$ & $\%$ & Erkek & Kadın \\
\hline \multicolumn{15}{|l|}{ BKİ(kg/m²) } \\
\hline Zayıf & - & - & - & - & 3 & 18.8 & - & - & 3 & 9.4 & - & - & \multirow{5}{*}{\multicolumn{2}{|c|}{$0.014 \quad 0.0001$}} \\
\hline Normal & 5 & 31.2 & 8 & 14.8 & 10 & 62.4 & 42 & 77.7 & 15 & 46.9 & 50 & 46.3 & & \\
\hline Hafif şişman & 6 & 37.6 & 30 & 55.6 & 3 & 18.8 & 9 & 16.7 & 9 & 28.1 & 39 & 36.1 & & \\
\hline Obez & 5 & 31.2 & 16 & 29.6 & - & - & 3 & 5.6 & 5 & 15.6 & 19 & 17.6 & & \\
\hline Toplam & 16 & 100.0 & 54 & 100 & 70 & 100 & 54 & 100 & 32 & 100 & 108 & 100 & & \\
\hline \multicolumn{15}{|c|}{ Bel-kalça oranı* } \\
\hline Normal & 6 & 37.5 & 24 & 44.4 & 9 & 56.2 & 47 & 87.0 & 15 & 46.9 & 71 & 65.7 & \multirow{3}{*}{\multicolumn{2}{|c|}{$0.288 \quad 0.0001$}} \\
\hline Normal üstü & 10 & 62.5 & 30 & 55.6 & 7 & 43.8 & 7 & 13.0 & 17 & 53.1 & 37 & 34.3 & & \\
\hline Toplam & 16 & 100.0 & 54 & 100 & 70 & 100 & 54 & 100 & 32 & 100 & 108 & 100 & & \\
\hline
\end{tabular}

Veriler sayı yüzde olarak verilmiştir

${ }^{\S}$ Ki-kare $\left(\chi^{2}\right)$ testi ve gözelerde frekans sayısının 5'ten küçük olduğu durumlarda Fisher-exact testi uygulanmıştır.

$B K \dot{I}\left(\mathrm{~kg} / \mathrm{m}^{2}\right)$ : Beden kütle indeksi

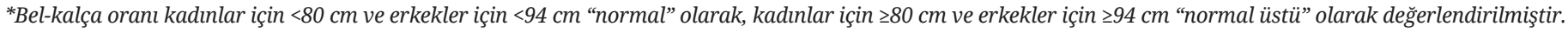


Grupların HDL düzeylerinin dağılımı incelendiğinde, vardiyalı çalışan bireylerin \%.37.1'inin HDL düzeyinin normal (erkeklerde $\geq 40$, kadınlarda $\geq 50$ ), \%62.9'unun normalin altında (erkeklerde <40, kadınlarda $<50$ ), kontrol grubundaki bireylerde ise bu oranin sırasıyla \%32.9 ve \%67.1 olduğu görülmüştür. Gruplar arasındaki bu fark istatistiksel olarak anlamlı değildir $(\mathrm{p}>0.05)$.

Katılımcıların trigliserit düzeylerine göre dağılımları incelendiğinde, vardiyalı çalışan grubun \%.40.0'ının normal ( $<150 \mathrm{mg} / \mathrm{dL}), \% 60.0$ 'ının normalin üzerinde ( $\geq 150 \mathrm{mg} / \mathrm{dL}$ ), kontrol grubununsa \%45.7'sinin normal, \%54.3'ünün normalin üzerinde trigliserit $(\mathrm{mg} / \mathrm{dL})$ düzeyine sahip olduğu belirlenmiştir. Vardiyalı çalışan bireylerin ve kontrol grubunun trigliserit düzeyleri arasındaki fark istatistiksel olarak anlamlı bulunmamıştır ( $\mathrm{p}>0.05)$.

Gruplar arasında açlık kan glukozu düzeyleri karşılaştırıldığında, vardiyalı çalışan grubun \%.64.3'ünün normal (<100 mg/dL), \%35.7'sinin normalin üzerinde $(\geq 100 \mathrm{mg} / \mathrm{dL})$ açlık kan glukozu düzeyine sahip olduğu, kontrol grubunun ise \%72.9'unun normal, \%27.1'inin normalin üzerinde açlık kan glukozu (mg/dL) düzeyine sahip olduğu belirlenmiştir. Çalışma şekline göre açlık kan glukozu düzeyleri arasındaki bu fark istatistiksel olarak önemli değildir ( $p>0.05)$.

Grupların kan basınçları karşılaştırıldığında ise, vardiyalı çalışan grubun \%55.7'sinin normal (sistolik kan basıncı $<130 \mathrm{mmHg}$, diastolik kan basınc $<85$ mmHg), \%44.3'ünün normalin üzerinde (sistolik kan basıncl $\geq 130 \mathrm{mmHg}$, diastolik kan basıncı $\geq 85$ mmHg) kan basincına sahip olduğu görülürken, kontrol grubunda bu oranlar sirasiyla \%48.6 ve \%52.4 olarak saptanmıştır. Çalışma şekline göre oluşturulan grupların kan basıncı düzeyleri arasındaki bu fark istatistiksel olarak önemli değildir ( $p>0.05)$.

Tüm bu sonuçlara göre MetS durumları karşılaştırıldığında, vardiyalı çalışan grubun \%47.1'inde MetS olduğu görülmüş ve çalışma şekline göre oluşturulan grupların MetS görülme durumları arasında istatistiksel olarak anlamlı fark saptanmıştır $(\mathrm{p}<0.001)$.

Tablo 4. Bireylerin IDF-2005 metabolik sendrom tanı kriterlerine göre karşılaştırılması

\begin{tabular}{|c|c|c|c|c|c|c|c|}
\hline \multirow{2}{*}{ Değişkenler } & \multicolumn{2}{|c|}{ Vardiyalı grup } & \multicolumn{2}{|c|}{ Kontrol grubu } & \multicolumn{2}{|c|}{ Toplam } & \multirow{2}{*}{$\mathrm{p} \S$} \\
\hline & $\mathbf{n}$ & $\%$ & $\mathbf{n}$ & $\%$ & $\mathbf{n}$ & $\%$ & \\
\hline \multicolumn{8}{|l|}{ Bel çevresi (cm) } \\
\hline Erkeklerde $<94$ kadınlarda $<80$ & 22 & 31.4 & 54 & 77.1 & 76 & 54.3 & \multirow{2}{*}{$<0.001$} \\
\hline Erkeklerde $\geq 94$ kadınlarda $\geq 80$ & 48 & 68.6 & 16 & 22.9 & 64 & 45.7 & \\
\hline \multicolumn{8}{|l|}{ HDL (mg/dL) } \\
\hline Erkeklerde $\geq 40$ kadınlarda $\geq 50$ & 26 & 37.1 & 23 & 32.9 & 49 & 35.0 & \multirow{2}{*}{$>0.05$} \\
\hline Erkeklerde $<40$ kadınlarda $<50$ & 44 & 62.9 & 47 & 67.1 & 91 & 65.0 & \\
\hline \multicolumn{8}{|l|}{ Trigliserit (mg/dL) } \\
\hline$<150$ & 28 & 40.0 & 32 & 45.7 & 60 & 42.9 & \multirow{2}{*}{$>0.05$} \\
\hline$\geq 150$ & 42 & 60.0 & 38 & 54.3 & 80 & 57.1 & \\
\hline \multicolumn{8}{|l|}{ Açlık kan glukozu (mg/dL) } \\
\hline$<100$ & 45 & 64.3 & 51 & 72.9 & 96 & 68.6 & \multirow{2}{*}{$>0.05$} \\
\hline$\geq 100$ & 25 & 35.7 & 19 & 27.1 & 44 & 31.4 & \\
\hline \multicolumn{8}{|l|}{ Kan basınci (mmHg) } \\
\hline SKB $<130$, DKB $<85$ & 39 & 55.7 & 34 & 48.6 & 73 & 52.1 & \multirow{2}{*}{$>0.05$} \\
\hline $\mathrm{SKB} \geq 130, \mathrm{DKB} \geq 85$ & 31 & 44.3 & 36 & 51.4 & 67 & 47.9 & \\
\hline \multicolumn{8}{|l|}{ MetS } \\
\hline Var & 33 & 47.1 & 13 & 18.6 & 46 & 32.9 & \multirow{2}{*}{$<0.001$} \\
\hline Yok & 37 & 52.9 & 57 & 81.4 & 94 & 67.1 & \\
\hline
\end{tabular}

SKB: Sistolik kan basincl, DKB: diastolik kan basincı MetS: Metabolik sendrom

HDL: Yüksek dansiteli lipoprotein-kolesterol

${ }^{s}$ Ki-kare $\left(\chi^{2}\right)$ testi uygulanmıştır. 
Bireylerin çalışma gruplarına ve cinsiyetlerine göre günlük enerji ve besin ögeleri alımlarının ortalama ve standart sapma değerleri Tablo 5'te verilmiştir. Enerji ve karbonhidrat alımlarına bakıldığında hem kadın hem de erkek vardiyalı çalışanların daha yüksek alımları olduğu görülmektedir $(p<0.05)$. Protein alımlarında kadınlarda anlamlı bir fark bulunmazken vardiyalı çalışan erkeklerin daha yüksek miktarda protein aldığı $(p<0.05)$, yağ alımlarına bakıldığında ise gruplar arasında anlamlı bir fark olmadığı görülmüştür ( $p>0.05)$.

Grupların tekli doymamış (MUFA) ve çoklu doymamış yağ asidi (PUFA) alımlarında da anlamlı bir fark saptanmamıştır ( $p>0.05)$. Vardiyalı kadınların daha fazla n-6 alımı olduğu ( $p<0.05)$, vardiyalı çalışan erkeklerin daha fazla kolesterol alımı olduğu $(p<0.05)$ ve vardiyalı çalışan bireylerin kontrol grubuna göre daha yüksek sodyum alımı olduğu görülmüştür $(\mathrm{p}<0.05)$.

Tablo 5. Çalışmaya katılan bireylerin günlük enerji ve besin ögeleri alım durumları

\begin{tabular}{|c|c|c|c|c|c|c|}
\hline \multirow{2}{*}{ Değişkenler } & \multicolumn{2}{|c|}{ Vardiyalı grup } & \multicolumn{2}{|c|}{ Kontrol grubu } & \multicolumn{2}{|c|}{$\mathbf{P}^{\S}$} \\
\hline & Kadın & Erkek & Kadın & Erkek & Erkek & Kadın \\
\hline Enerji (kkal) & $1959.1 \pm 559.7$ & $2369.4 \pm 552.3$ & $1534.4 \pm 492.8$ & $1769.1 \pm 613.2$ & 0.0001 & 0.030 \\
\hline Karbonhidrat (g) & $228.3 \pm 70.1$ & $283.5 \pm 72.1$ & $166.8 \pm 69.6$ & $188.3 \pm 70.6$ & 0.0001 & 0.018 \\
\hline Sakkaroz (g) & $35.8 \pm 21.7$ & $56.4 \pm 34.9$ & $25.7 \pm 22.4$ & $24.7 \pm 21.3$ & $\mathrm{p}>0.05$ & 0.0001 \\
\hline Lif (g) & $20.5 \pm 7.5$ & $23.1 \pm 8.2$ & $15.8 \pm 7.1$ & $21.3 \pm 12.9$ & $p>0.05$ & $p>0.05$ \\
\hline Protein (g) & $65.4 \pm 29.2$ & $83.7 \pm 29.6$ & $52.6 \pm 20.7$ & $62.7 \pm 26.8$ & $p>0.05$ & 0.0001 \\
\hline Yağ (g) & $80.7 \pm 24.4$ & $94.2 \pm 30.2$ & $70.7 \pm 31.9$ & $82.5 \pm 36.7$ & $\mathrm{p}>0.05$ & $p>0.05$ \\
\hline MUFA(g) & $28.5 \pm 11.2$ & $32.0 \pm 12.1$ & $25.6 \pm 13.5$ & $27.3 \pm 12.9$ & $\mathrm{p}>0.05$ & $\mathrm{p}>0.05$ \\
\hline Doymuş yağ (g) & $26.5 \pm 9.8$ & $31.7 \pm 13.4$ & $25.9 \pm 12.7$ & $25.2 \pm 10.4$ & 0.006 & $p>0.05$ \\
\hline PUFA (g) & $20.5 \pm 10.2$ & $22.9 \pm 13.4$ & $14.3 \pm 9.2$ & $24.9 \pm 16.1$ & $p>0.05$ & $p>0.05$ \\
\hline n-3 (g) & $1.9 \pm 0.9$ & $3.2 \pm 3.5$ & $2.7 \pm 1.8$ & $3.8 \pm 3.4$ & $\mathrm{p}>0.05$ & $\mathrm{p}>0.05$ \\
\hline $\mathrm{n}-6$ (g) & $18.6 \pm 10.3$ & $20.0 \pm 12.4$ & $11.6 \pm 8.2$ & $21.1 \pm 14.2$ & $\mathrm{p}>0.05$ & 0.041 \\
\hline Kolesterol (mg) & $203.8 \pm 111.1$ & $317.7 \pm 199.8$ & $214.3 \pm 238.4$ & $208.8 \pm 161.9$ & 0.002 & $\mathrm{p}>0.05$ \\
\hline Sodyum (mg) & $3936.7 \pm 1345.5$ & $4081.1 \pm 2345.5$ & $1429.9 \pm 736.6$ & $1732.9 \pm 950.4$ & 0.0001 & 0.0001 \\
\hline
\end{tabular}

Veriler ortalama \pm standart sapma olarak verilmiştir.

§Mann-whitney U testi veya t-test uygulanmiştir.

\section{TARTIŞMA}

Vardiyalı çalışma düzenin bireylerin biyolojik ritmini bozduğu ve bunun sonucunda birçok sağlık sorununa neden olduğu ileri sürülmektedir (10). Uyku bozukluğu, sirkadiyen ritmin bozulması, stres, azalmış fiziksel aktivite, beslenme alışkanlığı değişikliği, obezite, abdominal yağlanma, insülin direnci, diyabet, metabolik sendrom gibi bir çok bozukluk ve kronik hastalık için vardiyalı çalışma bir risk etmeni olarak değerlendirilmektedir (15-17,2529).

Vardiyalı çalışmanın uyku bozuklukları ile ilişkili olduğu ve bu durumun dikkatsizliği arttırarak iş performansını düşürdüğü ve iş kazalarına neden olduğu belirtilmektedir (28-30). Bu çalışmada da vardiyalı çalışan bireylerin uyku kalitesinin kontrol grubuna göre daha kötü olduğu istatistiksel olarak anlamlı saptanmıştır. Bu çalışmaya benzer olarak diğer çalışmalarda da vardiyalı çalışmanın uyku kalitesinin bozulmasıyla ilişkili olduğu bulunmuştur (25-27).

Vardiyalı çalışma ağırlık kazanımı ve bozulmuş glukoz metabolizması ile ilişkili bulunsa da diğer metabolik değişimlerle doğrudan ilişkisi saptanamamıştır (31). Bu durumun, uyku-uyanıklık döngüsü, termogenez, 
yiyecek tüketimi, yağ ve glukoz metabolizmasının sirkadiyen sistemin kontrolünde olmasindan kaynaklanıyor olabilmektedir (32). Bu çalışmada da vardiyalı çalışma obezite (bel çevresi) ile ilişkili bulunsa da açlık kan glukozu dahil diğer metabolik sendrom bileşenleri ile ilişkili bulunmamıştır. Bunun yanı sıra, vardiyalı çalışan bireylerin kolesterol düzeylerinin kontrol grubuna göre daha yüksek olduğu, ancak trigliserit düzeyleri arasında bir fark olmadığı bildirilmiştir (33).

Vardiyalı çalışmanın dinlenme ve günlük kan basıncı üzerindeki etkileri üzerine birçok çalışma yapılmıştır ancak çalışmaların her birinden farklı sonuçlar elde edilmiştir. Bazı çalışmalar vardiyalı çalışma ile doğru orantılı bir artış saptarken kimi çalışmalar da bir ilişki bulanamamıştır $(31,34)$. Bu araştırmada da kan basınçları ile çalışma şekli arasında bir ilişki saptanmamıştır. MetS ve vardiyalı çalışma arasındaki beklenen ilişkiyi saptayan bazı çalışmalar bulunmaktadır (16,35). Prospektif çalışmalara göre vardiyalı çalışma MetS için bağımsız bir risk etmenidir (11-12,36,37). Bu çalışmadan elde edilen bulgulara göre de vardiyalı çalışmanın metabolik sendrom riski ile ilişkili olabileceği söylenebilmektedir.

Vardiyalı çalışan bireylerin enerji, karbonhidrat ve sodyum alımı kontrol grubundan daha yüksek bulunmuş $(p<0.05)$, vardiyalı çalışan bireylerin çalıştıkları günlerde alınan besin tüketimi kayıtlarında daha çok paketli ve kolay tüketilebilir, enerji ve karbonhidrat içeriği yüksek ürünler tercih ettiği ve sodyum, karbonhidrat ve enerji alımlarının bu nedenle yükseldiği gözlenmiştir (veriler tabloda gösterilmemiştir). Benzer olarak, bir çalışmada da vardiyalı çalışan bireylerin daha yüksek enerji aldığı ve besin ögesi alımlarında bir farklılığın olmadığı saptanmıştır (38). Başka bir çalışmada (39) ise vardiyalı çalışan bireylerin daha yüksek enerji alımları olduğu ve doymuş yağ asidi alımlarının daha fazla olduğu görülmüştür.

Sonuç olarak, bu çalışmada MetS kriterlerinden sadece bel çevresi kriterinde anlamlı farklılık görülmüştür. Ancak sonuçlar vardiyalı çalışmanın bireylerin uyku kalitelerini düşürebilecek ve obezite riskini arttırabilecek bir etmen olduğunu düşündürmektedir. $\mathrm{Bu}$ nedenle daha uzun bir dönem boyunca vardiya sisteminde çalışan bireylerle yapılmış çalışmalara gerek duyulmaktadır. Bunun yanında vardiyalı çalışan bireyler ve vardiyalı çalışmanın olduğu iş kollarındaki yöneticilerin vardiyalı çalışmanın sağlık etkileri konusunda bilgilendirilmesi gerekmektedir.

Çıkar çatışması - Conflict of interest: Yazarlar çıkar çatışması olmadığını beyan ederler. - The authors declare that they have no conflict of interest.

Teşekkür - Acknowledgment: Bu makale "Vardiyall Çalışan İş̧ilerde Beslenme Durumu, Uyku Kalitesi ve Bazı Biyokimyasal Bulgular” başlıkl yüksek lisans tezine dayanmaktadır. Bahçeşehir Üniversitesi, Sağllk Bilimleri Fakültesi öğrencilerinden Buse Doğan, İdil Ayırtçı, Emine Yaz, Buse Yaman, Betül Sirma Onaycı ve Hasan Basri Işlk'a verilerin toplanmasındaki değerli katkılarından dolayı teşekkür ederiz.

\section{KAYNAKLAR}

1. Bilir N. İş Sağllğı ve Güvenliği. 1. Baskı. Ankara, Hacettepe Üniversitesi Yayınları; 2016.

2. Guo Y, Liu Y, Huang X, Rong Y, He M, Wang Y, et al. The effects of shift work on sleeping quality, hypertension and diabetes in retired workers. PLoS One 2013;8:e71107.

3. Yıldız AN, Gedikli FG, Biçer BK. Türkiye İşçi Sendikaları Konfederasyonu. Vardiyalı çalışmalarda iş sağlığı ve güvenliği konuları. Ankara: Aydoğdu Ofset 2012,2:64-5.

4. Eurofound. Fifth European Working Conditions Survey. 2012. Available at: http://www.eurofound.europa.eu/ tr/surveys/2010/fiftheuropean-working-conditionssurvey-2010. Accessed: August 08, 2015.

5. Health and Safety Executive. Managing Shiftwork Health and Safety Guidance. 2006. Available at: http:// www.hse.gov.uk/pubns/priced/hsg256.pdf. Accessed: August 10, 2015.

6. Türkiye İstatistik Kurumu (TÜiK). İşgücü İstatistikleri, Kurumsal Olmayan Sivil Nüfusun Ylllar ve Cinsiyete Göre İşgücü Durumu (2000 Yllı ve Sonrasına İlişkin Sonuçlar Türkiye). 2002. Erişim: http://www.tuik.gov. tr/PreTablo.do?tb_id=23\&ust_id=7\&tk_id=6365. Erişim tarihi: 17 Haziran 2015.

7. European Foundation for the Improvement of Living and Working Conditions. Working conditions in the acceding and candidate countries. 2003. Available at:http://www.eurofound.europa.eu/sites/default/files/ 
ef_files/pubdocs/2003/06/tr/1/ef0306tr.pdf. Accessed: June 17, 2015.

8. Rosa RR, Colligan MJ. Plain language about shiftwork, 1997. Available at:http://www.cdc.gov/niosh/docs/97145/pdfs/97-145.pdf. Accessed: July 12, 2015.

9. Sun M, Feng W, Wang F, Li P, Li Z, Li M, et al. Meta analysis on shift work and risks of specific obesity types. Obes Rev 2018;19(1):28-40.

10. Papantoniou K, Devore EE, Massa J, Strohmaier S, Vetter C, Yang L, et al. Rotating night shift work and colorectal cancer risk in the nurses' health studies. Int J Cancer 2018;143(11):2709-17.

11. De Bacquer D, Van Risseghem M, Clays E, Kittel F, De Backer G, Braeckman L. Rotating shift work and the metabolic syndrome: a prospective study. Int J Epidemol 2009;38:848-54.

12. Lin YC, Hsiao TJ, Chen PC. Persistent rotating shiftwork exposure accelerates development of metabolic syndrome among middleaged female employees: A fiveyear follow-up. Chronobiol Int 2009;26:740-55.

13. Savard J, Josee L, Laroche H, Liny S, Simard CM. Chronic insomnia and immune functioning. Psychosom Med 2003;65(2):211-21.

14. Lajoie P, Aronson KJ, Day A, Tranmer J. A cross-sectional study of shift work, sleep quality and cardiometabolic risk in female hospital employees. BMJ Open 2015;5(3):e007327.

15. Rhéaume A, Mullen J. The impact of long work hours and shift work on cognitive errors in nurses. J Nurs Manage 2018;26(1):26-32.

16. Korsiak J, Tranmer J, Day A, Aronson KJ. Sleep duration as a mediator between an alternating day and night shift work schedule and metabolic syndrome among female hospital employees. Occup Environ Med 2018;75(2):1328.

17. Itani O, Kaneita Y, Tokiya M, Jike M, Murata A, Nakagome $\mathrm{S}$, et al. Short sleep duration, shift work, and actual days taken off work are predictive life-style risk factors for new-onset metabolic syndrome: a seven-year cohort study of 40,000 male workers. Sleep Med 2017;39:87-94.

18. Ağargün MY, Kara H, Anlar O. Pittsburgh Uyku Kalitesi İndeksi'nin geçerliği ve güvenirliği. Turk Psikiyatr Derg 1996;7:107-11.

19. Erhardt J. BeBis: Nutrition Data Base Software. İstanbul; 2004.

20. Arabacı R, Çankaya C. Beden eğitimi öğretmenlerinin fiziksel aktivite düzeylerinin araştırılması. Uludağ Üniversitesi Eğitim Fakültesi Dergisi 2007;1-15.

21. Öztürk M. Üniversitede eğitim gören öğrencilerde uluslararası fiziksel aktivite anketinin geçerliliği ve güvenilirliği ve fiziksel aktivite düzeylerinin belirlenmesi [Bilim Uzmanlığı Tezi]. Hacettepe Üniversitesi Sağllk Bilimleri Enstitüsü, Ankara; 2005.

22. Baysal A, Aksoy M, Besler HT, Bozkurt N, Keçecioğlu S, Mercanlıgil SM, ve ark. Diyet El Kitabı. 9. Baskı. Hatiboğlu Basın ve Yayım San. Tic. Ltd. Şti, Ankara, 2016.

23. Han TS, Leer EM, SeidellJC, Lean ME. Waist circumference action levels in the identification of cardiovascular risk factors: prevalance study in a random sample. BMJ Brit Med J 1995;311:1401-5.

24. International Diabetes Federation (IDF). The IDF consensus worldwide definition of the Metabolic Syndrome. 2006. Available at: https://www. idf.org/component/attachments/attachments. html?id=705\&task=download. Accessed: July 07, 2016.

25. Üstün Y, Şebnem Çınar Y. Hemşirelerin uyku kalitesinin incelenmesi. Maltepe Üniversitesi Hemşirelik Bilim ve Sanatı Dergisi 2011;4:29-38.

26. Gülser N, Öztürk L, Top MŞ, Asil T, Balcı K, Çelik Y. Vardiyalı çalışanlarda huzursuz bacaklar sendromu ve subjektif uyku kalitesi. Noropsikiyatri Ars 2012;49:2815.

27. Machi MS, Staum M, Callaway CW, Moore C, Jeong K, Suyama J, et al. The relationship between shift work, sleep, and cognition in career emergency physicians. Acad Emerg Med 2012;19(1):85-91.

28. Barger LK, Lockley SW, Rajaratnam SM, Landrigan CP. Neurobehavioral, health, and safety consequences associated with shift work in safety-sensitive professions. Curr Neurol Neurosci Rep 2009;9:155-64.

29. Rajaratnam SM, Barger LK, Lockley SW, Shea SA, Wang W, Landrigan C, et al. Sleep disorders, health, and safety in police officers. JAMA 2011;306:2567-78.

30. Caruso CC. Negative impacts of shiftwork and long work hours. Rehabil Nurs 2014;39(1):16-25.

31. Proper KI, van de Langenberg D, Rodenburg W, Vermeulen RC, van der Beek A J, van Steeg H, et al. The relationship between shift work and metabolic risk factors: a systematic review of longitudinal studies. Am J Prev Med 2016;50(5):147-57.

32. Antunes LC, Levandovski R, Dantas G, Caumo W, Hidalgo MP. Obesity and shift work: chronobiological aspects. Nutr Res Rev 2010;23(1):155-68.

33. Akbari H, Mirzaei R, Nasrabadi T, Gholami-Fesharaki M. Evaluation of the effect of shift work on serum cholesterol and triglyceride levels. Iran Red Crescent Me 2015;17(1):e18723.

34. Souza BB, Monteze NM, de Oliveira FLP, de Oliveira JM, de Freitas SN, do Nascimento Neto RM, et al. Lifetime shift work exposure: association with anthropometry, body composition, blood pressure, glucose and heart rate variability. Occup Environ Med 2015;72(3):208-15. 
35. Esquirol Y, Bongard V, Mabile L, Jonnier B, Soulat JM, Perret B. Shift work and metabolic syndrome: respective impacts of job strain, physical activity, and dietary rhythm. Chronobiol Int 2009;26:544-59.

36. Pietroiusti A, Neri A, Somma G, Coppeta L, Iavicoli I, Berqamaschi A, et al. Incidence of metabolic syndrome among night-shift healthcare workers. Occup Environ Med 2010;67:54-7.

37. Guo Y, Rong Y, Huang X, Lai H, Luo X, Zhang Z, et al. Shift work and the relationship with metabolic syndrome in chinese aged workers. Plos One 2015;10(3):e0120632.

38. Hulsegge G, Boer J, van der Beek AJ, Verschuren WM, Sluijs I, Vermeulen R, et al. Shift workers have a similar diet quality but higher energy intake than day workers. Scand J Work Env Hea 2016;42(6):459-68.

39. Hemiö K, Puttonen S, Viitasalo K, Härmä M, Peltonen M, Lindström J. Food and nutrient intake among workers with different shift systems. Occup Environ Med 2015;72(7):513-20. 